\title{
Beyond the Veto
}

\section{Roles in UN Security Council Decision-Making}

\author{
Jess Gifkins | ORCID: 0000-0003-0551-787X \\ The University of Manchester, Manchester, United Kingdom \\ jess.gifkins@manchester.ac.uk
}

\begin{abstract}
The formal rules governing the UN Security Council offer little insight into how negotiations are conducted on a day-to-day basis. While it is generally assumed that permanent members dominate negotiations, this article investigates avenues for influence for elected members and the UN Secretariat. Institutional power is used to show how permanent members adopt dominant positions in negotiations extending far beyond their Charter-given privileges. Dominance of permanent members is moderated, however, by the legitimacy that support from elected members brings to a resolution. Similarly, the UN Secretariat can use its legitimated authority to influence decisions. The article argues that informal practices are key in understanding how power and influence are allocated in the Council and it forms a building block for future analyses of Security Council practices. This argument also has implications for the perennial reform debates and the prospects for informal reform.
\end{abstract}

\section{Keywords}

Security Council - decision-making - influence - legitimacy - institutional power practices 
Decisions made by the UN Security Council impact the lives of millions of people around the world, yet the decision-making process is largely informal and shrouded in secrecy. ${ }^{1}$ The formal rules governing this body-outlined in the UN Charter and the Provisional Rules of Procedure-provide a "skeleton" for understanding membership and voting in the Security Council, but tell us little about how it operates on a day-to-day basis. ${ }^{2}$ Studies on Security Council negotiations generally examine case studies. These might be specific conflicts or particular agenda items such as children and armed conflict, and the Women, Peace and Security agenda. ${ }^{3}$ Another, less common, approach is to focus on the individual foreign policies of key states within the Security Council. ${ }^{4}$ These approaches are necessary and useful for demonstrating the dynamics of the Council in relation to specific topics or foreign policy priorities; however, both downplay the background dynamics of the Security Council across issue areas and beyond individual foreign policies. Similarly, core books on the Council devote more attention to key areas of its work-peacekeeping, sanctions, terrorism - than to the Security Council as an entity and how its negotiations are conducted across issue areas. ${ }^{5}$ The recent practice turn has shed light on the process of negotiation and how outcomes are reached; however, this literature too has focused on conflicts or thematic areas. ${ }^{6}$ To understand how negotiations are conducted, in this article I argue that we need to first step back from specific matters on the Security Council's agenda and return to the roles occupied within Council decision-making - permanent members ( $\left.\mathrm{P}_{5}\right)$, elected members (E1O), and the UN Secretariat. Focusing on roles helps to demonstrate how influence operates within the Security Council and what types of influence different actors have.

My overarching argument - that permanent members dominate negotiations, but that elected members and the UN Secretariat have key avenues for influence-is not new and conforms with common assumptions about the

1 The author would like to thank James Pattison, Alex Bellamy, and Phil Orchard, and two anonymous reviewers for helpful comments on earlier versions of this article.

2 Schia 2013, 140.

3 Malone 1998, 2006; Thompson 2010; Adler-Nissen and Pouliot 2014; Ralph and Gifkins 2017; Cook 2016; Jacobsen and Engell 2018; Bode 2018; Bode and Karlsrud 2019; Kenkel and Stefan 2016.

4 Wenqi and Xinyu 2016; Tardy and Zaum 2016; Bosco 2016; Trenin 2016.

5 Lowe et al. 2008; von Einsiedel, Malone, and Stagno Ugarte 2016; Luck 2006; Malone 2004.

6 Adler-Nissen and Pouliot 2014; Ralph and Gifkins 2017; Bode 2018; Bode and Karlsrud 2019; Cook 2016; Jacobsen and Engell 2018. 
Security Council. Where this article contributes is via a detailed analysis of how each set of actors influences negotiations. I show how the dominance of permanent members extends beyond the formal rules. Institutional power mediates relationships between participants and enables the $\mathrm{P}_{5}$ to increase their influence via informal veto and by dominating drafting and agenda setting, all of which draws from their formal powers but extends beyond them. ${ }^{7}$ I demonstrate that the dominance of permanent members is mitigated by legitimacy and, in particular, the legitimation practices of drafters who prioritize unanimous decisions (above and beyond the legal requirements) and recognize the value of support from states in the region under discussion. Seeking legitimacy for a decision increases the influence of elected members. In addition to considerations of legitimacy, elected members can enhance their influence via collective action or the diplomatic capacities of their individual permanent mission in New York. While only Security Council members have a vote, I examine the UN Secretariat to show how the Secretary-General shapes the normative environment and the conceptual tools that are available to negotiators. Departments of the UN Secretariat also contribute directly to negotiations via briefings or reports, and their input carries the weight of legitimated authority. There is currently growing interest in understanding the influence and roles that both permanent members and elected members have in the Security Council, and this article contributes to that debate. ${ }^{8}$

I analyze the informal, and often unwritten, aspects of decision-making. Recognizing that the practices and processes of the Security Council are always in flux, I draw from a range of contemporary examples and literature. I proceed in four sections. First, I provide background on the formal structures that guide the Security Council, and why we need to supplement this with an account of institutional power and legitimacy. Second, I examine the roles of permanent members and how their dominance in the Council extends beyond their Charter-given privileges as an effect of institutional power. Third, I argue that although elected members' ability to individually determine the outcome of a decision is negligible, drafters seek legitimacy for decisions in the form of unanimity and regional support, which can enhance the influence of elected members. Elected members can also increase their influence by working collaboratively together and by having strong diplomatic capacities. Fourth, I note that the UN Secretariat can influence negotiations either by providing advice directly to the Security Council or by shaping the normative environment to

7 Barnett and Duvall 2005a, 2005b.

8 Langmore and Farrall 2016; Gifkins, Jarvis, and Ralph 2019a, 2019b; Farrall et al. 2020; Ralph, Gifkins, and Jarvis 2020. 
encourage specific types of decisions. I demonstrate the importance of considering the different roles within Security Council negotiations and the different avenues for influence that different roles afford, and note the implications for debates on UN reform.

The formal structure of the UN Security Council is deceptively simple. The UN Charter determines that this body has fifteen members, ${ }^{9}$ five that hold permanent seats-China, France, Russia, the United Kingdom, and the United States-and ten that hold two-year seats. The difference between permanent positions and short-term positions is magnified by the voting structure, giving permanent members the capacity to individually disallow a resolution via a negative vote, which is colloquially known as a "veto." 10 A vote can also fail if it does not reach the requisite nine affirmative votes. These simple rules form the basis of both membership and voting. In addition, formal rules set out in the Provisional Rules of Procedure govern aspects such as how meetings are called, who can attend meetings, and how the presidency is allocated. ${ }^{11}$ These formal rules are straightforward; however, they give little insight into how the Security Council operates on a day-to-day basis. The seeming simplicity of these institutional structures belies the rich history of informal practices of Council decision-making. Some of these practices are insignificant to decisionmaking - for example, the Secretary-General always sits to the right of the Council's president at the iconic horseshoe table. ${ }^{12}$ Other informal practices have considerable influence on which decisions are possible — such as which states lead negotiations and how it is decided whether an item will be added to the agenda. There is a gap, however, between the formal requirements - as set out in the UN Charter and the Provisional Rules of Procedure-and the resulting decisions taken by the Security Council, and this research focuses on the space in between.

9 The membership increased from eleven members to fifteen members in 1965 .

10 The term veto does not appear in the UN Charter. Article 27(3) calls for the "concurring" votes of permanent members; however, it was decided early in the Security Council's practice that an abstention was counted as "concurring" because an abstention was viewed as waiving the right to veto. For a discussion, see Bailey 1974.

11 UN 1982.

12 Sievers and Daws 2014, 62. 
In addition to the formal rules, in recent years Security Council members have attempted to collate Council working methods into a recurring series of notes, instigated by Japan, collected under the title Note 507. However, there is a key limitation in looking to these notes to understand the practice of decisionmaking because they describe how (some) Security Council members would like decision-making to operate. ${ }^{13}$ There is no clear distinction within the documents between sections that are descriptive and sections that are aspirational. For example, the practice of penholding - whereby one or more states take political ownership for drafting decisions on a given topic - is discussed in the 2017 Note 507, which stresses that "any member of the Security Council may be a penholder."14 This has also been stressed in previous Note 507s. Yet in practice, the United Kingdom, the United States, and France (Permanent Three, $\mathrm{P}_{3}$ ) maintain their stranglehold on the day-to-day practice of penholding. ${ }^{15}$ Thus there is a significant gap between the documented working methods and the day-to-day operation of the Council.

The roles and capacity for influence that different actors have are shaped by institutional power and legitimacy. Institutional power shapes the capacities available to states by mediating the relationships between actors. ${ }^{16}$ The dominance of permanent members extends far beyond their Charter-given privileges. Informally, permanent members dominate three key aspects of decisionmaking: drafting, agenda setting, and the potential leverage gained by "informal veto" threats. These informal practices matter because, as Rebecca AdlerNissen and Vincent Pouliot have explained, "While we already knew that the $\mathrm{P}_{3}$ call the shots at the Security Council, our understanding of how this is done in actual practice has remained rudimentary."17 The power of permanent members is not absolute, however; it is mediated by the legitimacy that elected members bring to a decision. Drafters use legitimation practices, such as seeking unanimity and regional support. Legitimacy here is understood as a social status that actors seek, and "involves being recognized as good, proper, or commendable by a group of others." ${ }^{18}$ Elected members can also bring strong diplomatic capacities to the negotiations or act in groups to enhance their influence. The UN Secretariat has legitimated authority and the capacity to shape

\footnotetext{
13 Security Council Report 2018b, 10.

14 UN Security Council 2017, 13.

15 Security Council Report 2019.

16 Barnett and Duvall 2005a, 2005b.

17 Adler-Nissen and Pouliot 2014, 909 (emphasis in original).

18 Coleman 2007, 20.
} 
negotiations either by providing recommendations to the Security Council or by shaping the normative environment via norm entrepreneurship.

\section{The Role of Permanent Members}

The roles adopted by the $\mathrm{P}_{5}$ can be best understood via the lens of institutional power. $\mathrm{P}_{5}$ dominance draws from their voting powers, but extends into other areas. The institutional structure of the Council creates greater disparities between permanent and elected members than the formal distinctions between them would suggest. ${ }^{19}$ The only formal difference between permanent and elected members is that permanent members have the capacity to veto decisions and have ongoing membership, while elected members serve two-year terms and cannot individually block decisions. The ongoing nature of $\mathrm{P}_{5}$ membership also has advantages in the form of institutional memory, relationships, and knowledge of the informal working methods. ${ }^{20}$ However, the socially sanctioned role that permanent members take up is larger than this. For example, since the 1980 s, the $\mathrm{P}_{5}$ meet separately as a semiformal practice to coordinate their positions and rotate the chair of this group between themselves every three months. ${ }^{21}$ Institutional power increases the dominance of permanent members in three key areas: the capacity for "informal veto," agenda setting, and penholding, each of which are addressed below.

First, as an effect of institutional power, permanent members hold an advantage simply by the existence of their veto powers - even without formally exercising them via casting a negative vote. While formal veto votes have been rare since the end of the Cold War, the informal veto remains a key potential in negotiations. ${ }^{22}$ Informal veto occurs when permanent members use the threat of veto to reject provisions of a resolution or an entire resolution during informal negotiations. An institutionalized example of informal veto comes from the "straw poll" ballots held when the Security Council selects a new SecretaryGeneral. This is not a formal vote, but is a prevote to indicate voting intentions, and permanent members use a different color so it becomes evident whether a veto would be likely if a formal vote were held for that candidate. ${ }^{23}$ In this example, permanent members do not need to issue a negative vote (which would be

\footnotetext{
19 Schia 2013, 139.

20 Luck 2006; Schia 2017; von Einsiedel, Malone, and Stagno Ugarte 2015.

21 Sievers and Daws 2014, 126.

22 Schindlmayr 2001, 225.

23 For a discussion, see Keating 2007.
} 
attached to their name), but can informally veto the proposed individual, preventing a formal vote on that candidate. This is an example of how institutional power-mediating relationships between participants-can shape the informal practices of the Council and influence which decisions are possible.

Situations where the threat of a veto blocks a resolution in its entirety are rare. A high-profile example of this occurred in the lead-up to the 2003 Iraq War when the United States sought a resolution that would formally authorize the use of force. Both Russia and France threatened to veto this so-called second resolution, which was not put to a vote. ${ }^{24}$ However, informal veto is more often used as leverage in a negotiation, whereby provisions are removed from a draft following a threat of veto. For example, in 2019 during debate toward a resolution on Women, Peace and Security, the United States threatened to veto the draft until provisions on sexual and reproductive health for survivors of sexual violence-provisions that had been included in previous resolutions - were removed. ${ }^{25}$ In the context of the draft referral of Sudan to the International Criminal Court (ICC) over crimes committed in Darfur, the United States obtained a highly coveted exemption from prosecution for individuals from nonparty states to the ICC's founding Rome Statute (excluding Sudan) after having threated to veto the draft. ${ }^{26}$ In both examples, the resolutions passed, although without key avenues of support or accountability envisaged by drafters. This shows how informal veto can impact outcomes; it does not necessarily prevent an output from being created, but it can limit the effectiveness of the output and create troubling precedents for subsequent decisions.

Second, permanent members have significant power to determine what is on the Council's agenda, ${ }^{27}$ which draws from the power permanent members have to veto decisions. Veto powers apply only to substantive (nonprocedural) questions, ${ }^{28}$ while adding items to the agenda is procedural and therefore the veto does not apply. ${ }^{29}$ In theory this means that there is no veto right on agenda setting, but in practice items are only occasionally added to the agenda against the wishes of a permanent member. As a social convention, dominance over agenda setting is not assumed equally by the $\mathrm{P}_{5}$, but predominantly by the $P_{3}$, with Russia and China showing little interest in adding new items to

\footnotetext{
24 Thompson 2010.

$25 \quad$ Allen and Shepard 2019.

26 Cryer 2006.

27 Boulden 2006; Wallensteen and Johansson 2004; UN 2004, 79.

28 UN 1945, Article 27(2).

29 Bailey and Daws 1998, 259.
} 
the agenda. ${ }^{30}$ For example, the United States and the United Kingdom resisted efforts to add the situation in Darfur to the agenda of the Security Council through late 2003 and early 2004 because they did not want to jeopardize the concurrent peace negotiations in Sudan between the government of Sudan and southern region of Sudan (now South Sudan). ${ }^{31}$ Being able to influence the agenda means that an actor can use their influence to promote values and practices that are inoffensive to them. ${ }^{32}$ This also includes conflict situations that receive limited engagement from the United Nations. For example, conflicts in states that border a $\mathrm{P}_{5}$ member and crises where one or more $\mathrm{P}_{5}$ members are part of the conflict are less likely to have extensive UN involvement than other conflicts. ${ }^{33}$ This agenda-setting role is not a formal privilege accorded to permanent members under the UN Charter, but it is an effect of institutional power where they assume this role for themselves.

Third, institutional power enables permanent members to dominate negotiations via informal penholding practices. Since 2008 agenda items have largely been divided between the $\mathrm{P}_{3}$ with each state assuming the role of penholder on a given issue. ${ }^{34}$ The penholder takes the lead on drafting decisions for a given conflict situation or thematic area and holds political ownership of the topic, meaning that if the penholder does not create a draft it is unlikely that other states will create one. ${ }^{35}$ By setting the terms of debate, drafters can give other states a choice between $\mathrm{X}$ or $\mathrm{Y}$ when really they prefer Z. ${ }^{36}$ The power to interpret a situation is inherently political. ${ }^{37}$ Penholding has been shown to be one of the primary means of influence within the Security Council. ${ }^{38}$ As a former German permanent representative explained, "The one who leads, the one who presents the text, who stakes out a position early in the day, is the one who more or less determines the game." ${ }^{39}$ In 2019, out of thirty-nine agenda items that had penholders, $\mathrm{P}_{3}$ members held thirty (77 percent) ${ }^{40} \mathrm{It}$ is worth noting that penholding also extends beyond drafting and includes, informally, organizing

\footnotetext{
$30 \quad$ von Einsiedel, Malone, and Stagno Ugarte 2015 .

31 Traub 2010; Kapila and Lewis 2013.

$32 \quad$ Bachrach and Baratz 1962, 948.

33 Beardsley and Schmidt 2012, 14.

34 Security Council Report 2013,2.

35 Ralph and Gifkins 2017.

$36 \quad$ Gruber 2005.

37 Jacobsen and Engell 2018.

38 Gifkins, Jarvis, and Ralph 2o19a.

39 Lynch 2014.

$40 \quad$ Security Council Report 2019.
} 
open debates, deciding whether to hold emergency meetings, and leading visits when the Security Council travels abroad. ${ }^{41}$

There is no indication of the penholding practice in the UN Charter, and the dominance of the $\mathrm{P}_{3}$ in this role, as well as the social acceptance of this domination, has evolved over time. This is similar to great-power dominance in the San Francisco negotiations that formalized the UN Charter; smaller states accepted this, however reluctantly, as a cost of getting great power buy-in for the institution. $^{42}$ Despite the informal nature of penholding, it has become a key feature of decision-making and the $\mathrm{P}_{3}$ resist attempts to challenge this system. ${ }^{43}$

Institutional power shapes Security Council negotiations toward $\mathrm{P}_{5}$, and especially $\mathrm{P}_{3}$, influence in three main ways: informal veto, the dominance of permanent members in agenda setting, and penholding. Critically, rather than coming directly from the UN Charter or from the Security Council's Provisional Rules of Procedure, these practices draw from the existence of the veto powers and permanent membership and the way that relationships between permanent and elected members are mediated by the formal institutional structures. These practices are not an inevitable outcome of the formal institutional structures; for example, there is nothing preventing China or Russia from adopting a more proactive role in drafting resolutions. Yet the penholder roles have largely been divided up between the $\mathrm{P}_{3}$. In 2019 China was not a penholder for any agenda items, and Russia was a penholder for Central Asia and joint penholder on Golan Heights. ${ }^{44}$ This division of labor is accepted, however unwillingly, as "the way things are done" by Council members, and forms a key part of the informal makeup of the Security Council.

\section{4 The Role of Elected Members}

The dominance of permanent members could indicate that elected members are of little significance to negotiations. Indeed, one study bluntly concluded that "a fair approximation as far as voting is concerned is that the Security Council has five members." ${ }^{45}$ Robert S. Junn and Barry O'Neil both argue that each individual elected member of the Council has almost no power, if you conceptualize "power" as the ability for an individual state to determine the

\footnotetext{
41 Security Council Report 2018a.

42 Hurd 2007, 95-105.

43 Schia $2017,61$.

44 Security Council Report 2019.

45 O’Neill 1996, 235.
} 
outcome of a particular vote. ${ }^{46}$ They each base their argument on statistical models of formal voting rules, however, and even though the power that permanent members wield extends beyond these formal rules, elected members can still have significance in negotiations. Critically, the institutional power that $\mathrm{P}_{5}$ members enjoy is mitigated by shared conceptions of legitimacy, which gives elected members a more significant role than their voting power alone suggests.

Legitimacy and legitimation have long been recognized as central concepts for the functioning of the Security Council. ${ }^{47}$ While most research on legitimacy in relation to the Council considers the legitimacy of the institution itself or its decisions, I analyze legitimacy in the negotiation process and use legitimacy as a "social status" drawing on Katharina Coleman's work. ${ }^{48}$ The argument is that states - particularly $\mathrm{P}_{3}$ members since they dominate draftingengage in legitimation practices inside Security Council negotiations and these practices enhance the role and influence of elected members in two main ways. First, drafters' privilege unanimous decisions so elected members can leverage this to enhance their influence. ${ }^{49}$ Second, when an elected member is from the region under discussion the "legitimacy value" of its support increases. In each of these scenarios the symbolic power of support from elected members increases, which in turn affords greater scope for leverage by elected members. ${ }^{50}$

First, unanimous decision-making is highly valued within the Security Council, so any threat to unanimous voting can increase the potential leverage of a dissenting state. ${ }^{51}$ Legally, the requirement to pass a resolution is only nine affirmative votes, with no negative votes from permanent members. Yet the vast majority of resolutions put to a vote in the Council since the end of the Cold War have not only passed, but passed unanimously. ${ }^{52}$ Between 2000 and 2020 there were 1,328 resolutions voted on in the Security Council, of which 87 percent passed with the support of all fifteen members. ${ }^{33}$ Unanimous voting is recognized as a mark of legitimacy within the Council and is seen to strengthen a decision and the likelihood that it will be implemented. For example, the for-

46 O’Neill 1996; Junn 1983.

47 Hurd 2007; Claude 1966; Thompson 2010.

48 Coleman 2007 .

49 Dunne and Gifkins 2011, 523.

$50 \quad$ Hurd 2002.

$5^{1} \quad$ There can also be some pressure to vote affirmatively (e.g., Schia 2013; Adler-Nissen and Pouliot 2014, 900) which is an area that warrants further research.

$5^{2} \quad$ Dunne and Gifkins 2011, 523.

53 While the average remains high, only 73 percent of draft resolutions passed unanimously in 2020 . This data was compiled by the author from UN 2020. 
mer Department of Peacekeeping Operations (DPKO) Capstone Report, lists unity among the key attributes that influence the success of a peacekeeping operation: "Anything other than unanimous Security Council backing can be a serious handicap." 54

To illustrate how this can be translated into influence, after a peacekeeping resolution was rejected by Sudan in 2006, Security Council members knew that it was particularly important that the next resolution on peacekeeping in Darfur was unanimous. The meeting record for the unanimous adoption of subsequent Resolution 1769 includes statements from both Qatar and Indonesia where they explain that they had reservations in supporting earlier drafts of the resolution, but that drafters accommodated their concerns in the draft so that they were able to vote for the resolution..$^{55}$ While Junn (1983) and O'Neil (1996) are right that individual elected members have limited power to determine the outcome of a vote, elected members can leverage more power in exchange for an affirmative vote due to the legitimation practices used by drafters.

Second, the legitimacy value of support from elected members is not equal between elected members; support from states that are within the region under discussion is especially prized by drafters. This support could be in the form of affirmative votes, cosponsorship, or other leadership roles. For example, a draft resolution on Syria in 2012 was initially led by the $\mathrm{P}_{3}$ before it was presented to the Council by Morocco, as the Arab representative on the Council. ${ }^{56}$ The think tank Security Council Report explained at the time of this draft: "Arab support is seen as crucial in getting a unanimous Council position on the Syria crisis." ${ }^{n 7}$ As such, Arab leadership on the draft was a legitimation practice to secure wider support. Similarly, a leaked US cable discusses a strategy where support from Ghana was sought for a draft resolution on Darfur, as a stepping stone toward gaining support from China, Qatar, and South Africa. ${ }^{58}$

These examples show how regional support can be a legitimation practice used by drafters to enhance wider support. The legitimacy that a regional state brings to negotiations can be translated into influence by that state. As described by a diplomat involved in the negotiations toward Security Council Resolution 1973 on Libya, Lebanon acted as a conduit between the Arab League and the Council explaining: "This is our patch, and we are telling you that you

\footnotetext{
54 DPKO 2008, 5 o.

55 UN Security Council 2007.

$5^{6} \quad$ Gifkins 2012, 385 .

57 Security Council Report 2012.

$5^{8}$ Wikileaks 2007.
} 
should do X, Y and Z."59 It was at the suggestion of Lebanon that the text "no foreign occupation" was added into Resolution 1973 as a political compromise that helped to facilitate support for the resolution. ${ }^{60}$ Regions are increasingly seen as playing a "gatekeeper" role and, while support from regional groups is sought, support from regionally relevant states is also prized in Security Council negotiations. ${ }^{61}$

These are not the only means of enhancing the influence of elected members, however. Elected members also can increase their capacity for influence via strategic means, either by collaborating with fellow elected members to act as a bloc, or by having strong diplomatic capacities in terms of their competencies in Security Council practices and the size and effectiveness of their diplomatic corp.

First, there is growing recognition from elected members that they can magnify their influence by acting collectively. This development is a response to the frustrations of elected members at the dominance of permanent members in drafting. As Richard Gowan explained, "A nascent 'E1o culture' has emerged in recent years, with small and medium-sized countries working together across regional divides to make their presence felt." ${ }^{2}$ Elected Security Council members outlined their intentions to work more collectively in a series of documents in 2018. ${ }^{63}$ E1o members often have divergent foreign policies, but they have found strength in working collectively on topics where they can find common ground. For example, on Yemen a group of five elected members have worked together to submit joint proposals and have even threatened to "take the pen" from the UK, which is the penholder on Yemen. ${ }^{64}$ A different group of five elected members worked together to draft a resolution condemning attacks against medical facilities and personnel. ${ }^{65}$ Another prominent example is a revolving group of elected members that has taken over penholding for the humanitarian track of the Syrian conflict. ${ }^{66}$ While these small groups of elected members are not numerically large enough to block a decision, elected mem-

\footnotetext{
59 Adler-Nissen and Pouliot 2014, 901.

6o Adler-Nissen and Pouliot 2014, 901.

61 Bellamy and Williams 2011. In addition to regional leadership, there are also instances where informal groups form to address a specific conflict either inside or alongside the Security Council such as the $\mathrm{P}_{5}+1$ group that works on Iran negotiations; see Prantl 2005 .

62 Gowan 2019.

63 Sievers and Daws 2018.

64 Security Council Report 2019; Martin 2018.

65 Martin 2018.

66 Langmore and Farrall 2016; Ralph and Gifkins 2017.
} 
bers have recognized the power of acting in groups where possible to magnify their leverage.

Second, elected members can increase their influence via their diplomatic capacity. The duration of tenure for permanent members means that they benefit from institutional memory and detailed knowledge of procedures and precedents. ${ }^{67}$ Even experienced UN diplomats describe a steep learning curve when taking up an elected position in the Security Council, while the $\mathrm{P}_{5}$ are "old hands, comfortable in their skins." 68 Elected members can mitigate their institutional disadvantage via diplomatic capacity, meaning both competence in Security Council practices and the size and reach of their diplomatic infrastructure. Diplomatic capacities have been shown to be key to a state's capacity for influence in the Security Council, both in general and for elected members specifically. ${ }^{69}$ States taking up a seat in the Council can ramp up their skills and knowledge such as Sweden's strategy of building a database of agenda items and positions of states, and Norway's strategy of drawing on knowledge via partnerships with universities and think tanks. ${ }^{70}$ Competence in diplomatic practices can enhance the ways in which elected members are able to influence decision-making. For example, Australia used diplomatic skill and constructive relationships to secure a resolution calling for an investigation following the downing of Malaysian Airlines flight MH17, despite Russian resistance to this proposal. ${ }^{71}$ Elected members can also benefit from engaging in "niche diplomacy" during their tenure, and using their presidency to facilitate debates on favored topics can be a useful strategy. ${ }^{72} \mathrm{An}$ area where elected members dominate is chairing Sanctions Committees, which are subsidiary bodies of the Security Council, giving them influence over how sanctions are applied. ${ }^{73}$ Through diplomatic skill and activism, some elected members can and do "punch above their weight."

The scenarios and attributes that can increase E1o influence should not be overstated, however. Much of the decision-making, particularly on contentious issues, occurs between permanent members with limited capacity for input from elected members. This is clearly reflected in the timing of negotiations,

\footnotetext{
67 Security Council Report 2018b; Farrall et al 2020.

68 Rosenthal 2017, 94-95.

69 Gifkins, Jarvis, and Ralph 2019a; Farrall et al 2020.

$70 \quad$ Thorhallsson 2012.

$71 \quad$ Langmore and Farrall 2016.

72 Lupel and Mälksoo 2019; Farrall et al 2020.

73 Eckert 2016. This article does not focus on the Security Council's subsidiary bodies. For further discussion on the decision-making process in Sanctions Committees see Gehring and Dörfler 2013.
} 
whereby drafts are generally negotiated and agreed by the $\mathrm{P}_{3}$, then negotiated with Russia and China. Only then, once a balance has been reached, are drafts shared with elected members, with limited time before a vote and discouragement from drafters for substantive change. ${ }^{74}$ By the time drafts are circulated to the E1o, they have "a de facto disclaimer: do not call for amendments that might upset the consensus achieved among permanent members."75 E1o members describe frustration at a role that often feels like providing a "rubber stamp" to decisions that have already been made by permanent members. ${ }^{76}$ While legitimation practices used by drafters and diplomatic capacity from elected members can increase the potential for input from elected members, this remains limited in a system that is weighted toward permanent members that dominate drafting and can individually block decisions.

\section{The Role of the UN Secretary-General and Secretariat}

The other set of actors with direct input into Security Council negotiations is the UN Secretary-General and the Secretariat more broadly. This group of actors is sometimes known as the "second UN," where the "first UN" is the intergovernmental fora. ${ }^{77}$ The Secretariat does not have a vote in Security Council negotiations but has the capacity to influence decision-making, nonetheless. The Secretariat has legitimated authority that enhances its capacity for influence. ${ }^{78}$ This can be done via the role of the Secretary-General, which can have a constitutive impact on the social environment which in turn encourages certain types of decisions. By doing so, the Secretariat can create a linguistic and political repertoire that enables normative change and the development of new tools. The other way that the second UN can shape decisions is by providing information and advice that informs decisions. International organizations can act as seemingly neutral information providers with legitimated authority. ${ }^{79}$ In this way information provided by Secretariat departments is often held

\footnotetext{
74 von Einsiedel, Malone, and Stagno Ugarte 2015.

75 Nadin 2016, 108.

76 Ralph and Gifkins 2017, 643 .

77 Weiss, Forsythe, and Coate 2007. The "third UN" (i.e., nongovernmental organizations and the epistemic community around the UN) can also impact decisions; however, this analysis focuses on the first and second UNs because they have regular formal input into negotiations.

78 Cronin and Hurd 2008.

79 Abbott and Snidal 1998.
} 
in high esteem, even though institutions can have their own political interests that can drive their advice. ${ }^{80}$

Former head of the Department of Peace Operations (DPO), ${ }^{81}$ Jean-Marie Guéhenno, has said of the Secretariat: "It actually has much more power than is generally assumed, and except for the few crises where a major power has a strategic interest, the Secretariat can often be in the driver's seat, like a sixth permanent member of the council." ${ }^{2}$ There are clear limits to the Secretariat's influence, however; where powerful states have strategic interests in a situation, the Secretariat is curtailed. The UN Secretary-General and Secretariat can shape decisions directly by providing information and recommendations or indirectly by promoting a normative environment that enables particular types of decisions, both of which are discussed in turn below.

First, the UN Secretary-General can provide normative guidance for the Security Council via norm entrepreneurship and as a moral leader. The office of the Secretary-General has been described as "responsibility without power"; however, it does have the capacity for influence. ${ }^{83}$ The Secretary-General's political role comes from the existence of Article 99 of the UN Charter, which enables her or him to bring matters to the attention of the Security Council. ${ }^{84}$ This provision is rarely formally invoked, but it increases the political capacity of the Secretary-General's role. ${ }^{85}$ Secretaries-General can increase their influence by acting as a "norm entrepreneur." The office of the Secretary-General has a unique capacity for norm entrepreneurship. ${ }^{86}$ Norm entrepreneurs frame issues in innovative ways and shape the agenda in new directions. ${ }^{87}$ Prominent examples of past Secretaries-General acting as norm entrepreneurs are: Dag Hammarskjold and his advocacy on armed peacekeeping; Boutros BoutrosGhali's advocacy on democratization; and Kofi Annan and his advocacy on the responsibility to protect. ${ }^{88}$ By contributing to the normative environment in the Security Council, the Secretary-General can help shape the conceptual tools that are available to states when making decisions on matters of international peace and security. Secretaries-General can also have normative influ-

\footnotetext{
8o Barnett and Finnemore 2004.

81 The Department of Peace Operations was called the Department of Peacekeeping Operations at the time.

$82 \quad$ Guéhenno 2015, 312.

83 Urquhart 2007, 31.

84 UN 1945 .

85 Kille 2005 .

86 See, for example, Adebajo 2007; Johnstone 2007; Rushton 2008.

$87 \quad$ Finnemore and Sikkink 1998, 897.

88 Johnstone 2007 .
} 
ence by providing moral leadership. Although they cannot tell states what to do, "it is the job of the Secretary-General to make it harder for an international community to make manifestly wrong decisions, or to take no decision at all." ${ }^{89}$ Secretaries-General develop the conceptual tools that are then used by decision-makers and can provide moral leadership to encourage certain decisions from states.

Second, the Secretary-General and departments of the UN Secretariat also can shape individual decisions by providing expert recommendations that inform deliberations. The Secretary-General and Secretariat are perceived as technical experts with impartiality that gives their recommendations gravitas. ${ }^{90}$ For example, the DPO has a unique role in planning peacekeeping operations and advising the Security Council on resources, mandate, and strategy. The Council uses the DPO as impartial experts: "It is the [DPO] planners themselves who frame the options for UN engagement that are presented to the Security Council by the Secretary-General, right down to the mandate language. Although the Council can ignore or modify the Secretary-General's recommendations when authorizing peacekeeping missions, it typically follows his [sic] guidance closely."91 By providing recommendations for the Security Council, the DPO can shape the Council's response and its interpretation of the options available. Other Secretariat departments also guide Security Council decision-making. The Office for the Coordination of Humanitarian Affairs (OCHA) produces a regular Aide Memoire for the Consideration of Issues Pertaining to the Protection of Civilians in Armed Conflict. ${ }^{92}$ While this document is based on the past practices of the Security Council it can also be seen as an advocacy tool, as OCHA has identified the lack of consistency in Council language as a problem and it advocates greater consistency. ${ }^{93}$ By drawing together past language from Security Council resolutions into an accessible form, OCHA can encourage the Council toward more consistent use of language. The technical expertise of the UN Secretariat gives it some ability to shape the process and the outcome of negotiations toward its preferred outcomes.

\footnotetext{
89 Chesterman and Franck 2007, 240.

9o Barnett and Finnemore 2004.

91 Holt, Taylor, and Kelly 2009, 119.

92 See, for example, OCHA 2014a.

93 OCHA 2O14b.
} 
The formal rules that govern the UN Security Council-in the form of the UN Charter and the Provisional Rules of Procedure-offer little insight into the day-to-day process of negotiating decisions. Analyzing the informal, and often unwritten, rules that govern daily Security Council practices is necessary to understand how decisions are created and the types of influence different actors may have. In this article, I demonstrate the utility of stripping back analysis of the Security Council to the roles and capacities of actors within negotiations. By considering the roles of actors within negotiations-permanent members, elected members, and the UN Secretariat- the different forms of influence that they have come to the fore.

While there is often an assumption that permanent members dominate decision-making, it has been lamented that there is still limited understanding of how this dominance occurs. ${ }^{94}$ The framing of institutional power helps to explain how permanent members extend their power far beyond their formal privileges - via the way formal institutional structures mediate relationships between participants. As such, permanent members gain greater influence in drafting, agenda setting, and their capacity for informal veto, despite this influence being uncodified and informal. The dominance of permanent members, however, is mediated by legitimacy. While elected members have almost no power to individually determine the outcome of a negotiation, they are able to have some influence due to the drive toward unanimity, or as states from the region under discussion. Drafters seek the legitimacy that comes from E1o support and elected states can leverage that for influence. Individual E1o members can also have greater influence if they have strong diplomatic capacities or if they work collaboratively with other elected members. While only fifteen states can vote in the Security Council, the UN Secretariat can also have influence by shaping the normative environment or providing recommendations from a position of legitimated authority. By stripping back analysis of the Security Council to the roles of actors inside negotiations, this article forms a building block for subsequent studies on Security Council negotiations or practices.

The argument on how dominance and influence occur also has implications for the perennial debates over Security Council reform. As has been well established, the debates over formal reform - that is, change to the membership or voting rules set out in the UN Charter-are deadlocked. ${ }^{95}$ As such,

94 Adler-Nissen and Pouliot 2014.

95 Nadin 2016; Niemetz 2015. Formal amendment of the UN Charter requires ratification from two-thirds of the UN General Assembly and all five permanent members of the UN 
the most promising avenues for reform may be informal changes to practices or working methods..$^{96}$ The Security Council as an institution is continually adapting, which means that the informal practices are not set in stone but can change over time. ${ }^{97}$ The gains in recent years made by elected members working collaboratively in small groups-for example, on the Syrian humanitarian track-show that there is potential for elected members to take the initiative and make an impact where they have strong diplomatic skills and a narrowly targeted goal. Since 2018 elected members have sought to codify their intentions to collaborate and, while this is not a panacea, it does show that there are avenues for greater capacity for influence by elected members. There has also been growing frustration with the dominance of penholding by $\mathrm{P}_{3}$ members. A welcome step from the UK in 2019 was to co-penhold with Germany on Libyan sanctions, where Germany is the chair of the Libyan Sanctions Committee. ${ }^{98}$ Elected members gain specific expertise on sanctions during their tenure, as most Sanctions Committees are chaired by elected members, and expanding co-penholding on sanctions or other areas would enable elected members to have a more active role in drafting. These avenues for increased influence for elected members show that, while formal reform debates are deadlocked, there is potential for informal change that would facilitate broader participation in negotiations, away from the $\mathrm{P}_{3}$ stranglehold. The formal rules make up only a small component of the distribution of power and influence within the Security Council. The UN Charter and Provisional Rules of Procedure give structure to the Security Council but reveal little about how decisions are made, a process that has evolved informally over decades.

\section{Bibliography}

Abbott, Kenneth W., and Duncan Snidal. "Why States Act through Formal International Organizations." Journal of Conflict Resolution 42 (1) (1998), 3-32.

Adebajo, Adekeye. "Pope, Pharaoh, or Prophet? The Secretary-General after the Cold War." In Secretary or General? The UN Secretary-General in World Politics, ed. Simon Chesterman (Cambridge: Cambridge University Press, 2007), 139-157.

Security Council. While there is widespread agreement on the need for reform, there is no single model of reform that has enough support.

96 Wenaweser 2016; Niemetz 2015.

97 Luck 2016; MacKenzie 2015; Yamashita 2007.

98 Security Council Report 2019. 
Adler-Nissen, Rebecca, and Vincent Pouliot. "Power in Practice: Negotiating the International Intervention in Libya." European Journal of International Relations 20 (4) (2014), 889-911.

Allen, Louise, and Laura Shepherd. "In Pursuing a New Resolution on Sexual Violence Security Council Significantly Undermines Women's Reproductive Rights.” Women, Peace and Security blog, London School of Economics, 2019. https://blogs.lse.ac.uk/ wps/2019/o4/25/in-pursuing-a-new-resolution-on-sexual-violence-security-counci l-significantly-undermines-womens-reproductive-rights/.

Bachrach, Peter, and Morton S. Baratz. "Two Faces of Power." American Political Science Review 56 (4) (1962), 947-952.

Bailey, Sydney D. "New Light on Abstentions in the UN Security Council." International Affairs 5o (4) (1974), 554-573.

Bailey, Sydney D., and Sam Daws. The Procedure of the UN Security Council, 3rd ed. (Oxford: Oxford University Press, 1998).

Barnett, Michael N., and Raymond Duvall. "Power in Global Governance." In Power in Global Governance, eds. Michael N. Barnett and Raymond Duvall (Cambridge: Cambridge University Press, 2005a), 1-32.

Barnett, Michael N., and Raymond Duvall. "Power in International Politics." International Organization 59 (1) (2005b), 39-75.

Barnett, Michael N., and Martha Finnemore. Rules for the World: International Organizations in Global Politics (Ithaca: Cornell University Press, 2004).

Beardsley, Kyle, and Holger Schmidt. "Following the Flag or Following the Charter? Examining the Determinants of UN Involvement in International Crises, 19452002." International Studies Quarterly 56 (1) (2012), 33-49.

Bellamy, Alex J., and Paul D. Williams. "The New Politics of Protection? Cote d'Ivoire, Libya and the Responsibility to Protect." International Affairs 87 (4) (2011), 845-870.

Bode, Ingvild. "Reflective Practices at the Security Council: Children and Armed Conflict and the Three United Nations." European Journal of International Relations 24 (2) (2018), 293-318.

Bode, Ingvild, and John Karlsrud. "Implementation in Practice: The Use of Force to Protect Civilians in United Nations Peacekeeping." European Journal of International Relations 25 (2) (2019), 458-485.

Bosco, David L. "Commentary: The Permanent One's Search for Maximum Flexibility." In The UN Security Council in the Twenty-First Century, eds. Sebastian von Einsiedel, David M. Malone, and Bruno Stagno Ugarte (Boulder: Lynne Rienner, 2016), 75-81.

Boulden, Jane. "Double Standards, Distance and Disengagement: Collective Legitimization in the Post-Cold War Security Council." Security Dialogue 37 (3) (2006), 409-423. Chesterman, Simon, and Thomas M. Franck. "Resolving the Contradictions of the Office." In Secretary or General? The UN Secretary-General in World Politics, ed. Simon Chesterman (Cambridge: Cambridge University Press, 2007), 1-11. 
Claude, Inis L. "Collective Legitimization as a Political Function of the United Nations." International Organization 20 (3) (1966), 367-379.

Coleman, Katharina P. International Organisations and Peace Enforcement: The Politics of International Legitimacy (Cambridge: Cambridge University Press, 2007).

Cook, Sam. "The 'Woman-in-Conflict' at the UN Security Council: A Subject of Practice." International Affairs 92 (2) (2016), 353-372.

Cronin, Bruce, and Ian Hurd. "Introduction." In The UNSecurity Council and the Politics of International Authority, eds. Bruce Cronin and Ian Hurd (Oxon: Routledge, 20o8), $3^{-22 .}$

Cryer, Robert. "Sudan, Resolution 1593, and International Criminal Justice." Leiden Journal of International Law 19 (1) (2006), 195-222.

DPKO (Department of Peacekeeping Operations). "United Nations Peacekeeping Operations: Principles and Guidelines." 20o8. http://www.un.org/en/peacekeeping/ documents/capstone_eng.pdf.

Dunne, Tim, and Jess Gifkins. "Libya and the State of Intervention." Australian Journal of International Affairs 65 (5) (2011), 515-529.

Eckert, Sue. "The Role of Sanctions." In The UN Security Council in the 21st Century, eds. Sebastian von Einsiedel, David M. Malone, and Bruno Stagno Ugarte (Boulder: Lynne Rienner, 2016), 413-439.

Farrall, Jeremy, Marie-Eve Loiselle, Christopher Michaelsen, Jochen Prantl, and Jeni Whalen. "Elected Member Influence in the United Nations Security Council." Leiden Journal of International Law 33 (1), 101-115.

Finnemore, Martha, and Kathryn Sikkink. "International Norm Dynamics and Political Change." International Organization $5^{2}$ (4) (1998), 887-917.

Gehring, Thomas, and Tomas Dörfler. "Division of Labour and Rule-Based Decisionmaking within the UN Security Council: The Al-Qaeda/Taliban Sanctions Regime." Global Governance 19 (4) (2013), 567-587.

Gifkins, Jess. “The UN Security Council Divided: Syria in Crisis.” Global Responsibility to Protect 4 (3) (2012), 377-393.

Gifkins, Jess, Samuel Jarvis, and Jason Ralph. "Brexit and the UN Security Council: Declining British Influence?" International Affairs 95 (6) (2019a), 1349-1368.

Gifkins, Jess, Samuel Jarvis, and Jason Ralph. “Global Britain in the United Nations.” The United Nations Association of the UK, 2019b. https://www.una.org.uk/global-britain -united-nations.

Gowan, Richard. "Council of Despair? The Fragmentation of UN Diplomacy." International Crisis Group, 2019. https://www.crisisgroup.org/global/boo1-council-despair -fragmentation-un-diplomacy.

Gruber, Lloyd. "Power Politics and the Institutionalization of International Relations." In Power in Global Governance, eds. Michael Barnett and Raymond Duvall (Cambridge: Cambridge University Press, 2005), 102-129. 
Guéhenno, Jean-Marie. The Fog of Peace: A Memoir of International Peacekeeping in the 21st Century (Washington, DC: Brookings Institution, 2015).

Holt, Victoria, Glyn Taylor, and Max Kelly. Protecting Civilians in the Context of UN Peacekeeping Operations: Successes, Setbacks and Remaining Challenges (New York: UN, 2009).

Hurd, Ian. "Legitimacy, Power, and the Symbolic Life of the UN Security Council." Global Governance 8 (1) (2002), 35-51.

Hurd, Ian. After Anarchy: Legitimacy and Power in the United Nations Security Council (Princeton: Princeton University Press, 2007).

Jacobsen, Katja Lindskov, and Troels Gauslå Engell. "Conflict Prevention as Pragmatic Response to a Twofold Crisis: Liberal Interventionism and Burundi." International Affairs 94 (2) (2018), 363-380.

Johnstone, Ian. "The Secretary-General as Norm Entrepreneur." In Secretary or General? The UNSecretary-General in World Politics, ed. Simon Chesterman (Cambridge: Cambridge University Press, 2007), 123-138.

Junn, Robert S. "Voting in the United Nations Security Council." International Interactions: Empirical and Theoretical Research in International Relations 9 (4) (1983), 315-352.

Kapila, Mukesh, and Damien Lewis. Against a Tide of Evil: How One Man Became the Whistleblower to the First Mass Murder of the Twenty-first Century (Edinburgh: Mainstream, 2013).

Keating, Colin. "Selecting the World's Diplomat." In Secretary or General? The UN Secretary-General in World Politics, ed. Simon Chesterman (Cambridge: Cambridge University Press, 2007), 47-66.

Kenkel, Kai Michael, and Cristina G. Stefan. "Brazil and the Responsibility While Protecting Initiative: Norms and the Timing of Diplomatic Support." Global Governance 22 (1) (2016), 41-58.

Kille, Kent J. From Manager to Visionary: The Secretary-General of the United Nations (New York: Palgrave Macmillan, 2005).

Langmore, John, and Jeremy Farrall. "Can Elected Members Make a Difference in the UN Security Council? Australia's Experience in 2013-2014." Global Governance 22 (1) (2016), 59-77.

Lowe, Vaughan, Adam Roberts, Jennifer Welsh, and Dominik Zaum, eds. The United Nations Security Council and War (Oxford: Oxford University Press, 2008).

Luck, Edward C. The UNSecurity Council:Practice and Promise (Oxon: Routledge, 2006). Luck, Edward C. "The UN Security Council at Seventy: Ever Changing or Never Changing." In The UN Security Council in the 21st Century, eds. Sebastian von Einsiedel, David M. Malone, and Bruno Stagno Ugarte (Boulder: Lynne Rienner, 2016), 195214.

Lupel, Adam and Lauri Mälksoo. “A Necessary Voice: Small States, International Law, 
and the UN Security Council." International Peace Institute, 2019. https:/www.ipinst .org/wp-content/uploads/2019/04/1904_A-Necessary-Voice_Final.pdf.

Lynch, Colum. “Can Washington Tame France's New Tart-Tongued Ambassador?" Foreign Policy, 9 September 2014. http://foreignpolicy.com/2014/o9/o9/can-washington -tame-frances-new-tart-tongued-ambassador/.

MacKenzie, David. "Forever Adaptable: The United Nations System at 7o." International Journal 70 (3) (2015), 489-498.

Malone, David M. Decision-Making in the UN Security Council: The Case of Haiti, 199o1997 (Oxford: Oxford University Press, 1998).

Malone, David M. ed. The UN Security Council: From the Cold War to the 21st Century (London: Lynne Rienner, 2004).

Malone, David M. The International Struggle over Iraq: Politics in the UN Security Council 1980-2005 (Oxford: Oxford University Press, 2006).

Martin, Ian. "In Hindsight: What's Wrong with the Security Council?" Security Council Report, 29 March 2018. http://www.securitycouncilreport.org/monthly-forecast/ 2018-04/in_hindsight_whats_wrong_with_the_security_council.php.

Nadin, Peter. UN Security Council Reform (Abingdon: Routledge, 2016).

Niemetz, Martin Daniel. Reforming UNDecision-Making Procedures: Promoting a Deliberative System for Global Peace and Security (Abingdon: Routledge, 2015).

O'Neill, Barry. "Power and Satisfaction in the United Nations Security Council." Journal of Conflict Resolution 40 (2) (1996), 219-237.

OCHA (Office for the Coordination of Humanitarian Affairs). "Aide Memoire for the Consideration of Issues Pertaining to the Protection of Civilians in Armed Conflict." Policy and Studies Series, 2014a. https:/docs.unocha.org/sites/dms/Documents/ aide\%2omemoire\%2O2014\%20-\%2oEnglish.pdf.

OCHA. "Security Council Norms and Practice on the Protection of Civilians in Armed Conflict: Analysis of Normative Developments in Security Council Resolutions 2009-2013." Policy and Studies Series, 2014b. https://docs.unocha.org/sites/dms/Doc uments/Security\%2oCouncil\%2oNorms_Final\%2oversion\%2ofor\%2oprint\%2017 \%20June\%2O2014.pdf.

Prantl, Jochen. "Informal Groups of States and the UN Security Council." International Organization 59 (3) (2005), 559-592.

Ralph, Jason, and Jess Gifkins. "The Purpose of United Nations Security Council Practice: Contesting Competence Claims in the Normative Context Created by the Responsibility to Protect." European Journal of International Relations 23 (3) (2017), $630-653$.

Ralph, Jason, Jess Gifkins, and Samuel Jarvis. "The UK's Special Responsibilities at the United Nations: Diplomacy after Brexit." British Journal of Politics and International Relations 22 (2) (2020), 164-181.

Rosenthal, Gert. Inside the United Nations: Multilateral Diplomacy up Close (Abingdon: Routledge, 2017). 
Rushton, Simon. "The UN Secretary-General and Norm Entrepreneurship: Boutros Boutros-Ghali and Democracy Promotion." Global Governance 14 (1) (2008), 95-110. Schia, Niels Nagelhus. "Being Part of the Parade- 'Going Native' in the United Nations Security Council." Political and Legal Anthropology Review 36 (1) (2013), 138-156.

Schia, Niels Nagelhus. "Horseshoe and Catwalk: Power, Complexity, and ConsensusMaking in the United Nations Security Council." In Palaces of Hope: The Anthropology of Global Organizations, eds. Ronald Niezen and Marie Sapignoli (Cambridge: Cambridge University Press, 2017), 55-77.

Schindlmayr, Thomas. "Obstructing the Security Council: The Use of the Veto in the Twentieth Century." Journal of the History of International Law 3 (2) (2001), 218-234.

Security Council Report. "Council Consultations on Draft Syria Resolution.", 27 January 2012. http://www.whatsinblue.org/2012/o1/council-consultations-on-draft-syria-res olution.php.

Security Council Report. "Monthly Forecast: September.", 29 August 2013. http://www .securitycouncilreport.org/atf/cf/\% $\%{ }_{7} \mathrm{~B}_{5} \mathrm{BFCF} 9 \mathrm{~B}-6 \mathrm{D}_{27}-4 \mathrm{E} 9 \mathrm{C}-8 \mathrm{CD}_{3}-\mathrm{CF} 6 \mathrm{E} 4 \mathrm{FF} 96 \mathrm{FF} 9$ \%7D/2013_o9_forecast.pdf.

Security Council Report. “The Penholder System.", 21 December 2018a. https://www .securitycouncilreport.org/atf/cf/\% $\%{ }_{7}$ B6 ${ }_{5} \mathrm{BFCF} 9 \mathrm{~B}-6 \mathrm{D} 27-4 \mathrm{E} 9 \mathrm{C}-8 \mathrm{CD}_{3}-\mathrm{CF} 6 \mathrm{E} 4 \mathrm{FF} 96 \mathrm{FF} 9$ $\% 7$ D/Penholders.pdf.

Security Council Report. "Security Council Working Methods: Provisional Progress.", 22 January 2018b. http://www.securitycouncilreport.org/atf/cf/\% $\%{ }_{3} 65$ BFCF9B-6D 27 -4E9C-8CD3-CF6E4FF96FF9\%7D/research_report_working_methods_2018.pdf.

Security Council Report. "Lead Roles within the Council in 2019: Penholders and Chairs of Subsidiary Bodies.", 31 January 2019. https://www.securitycouncilreport.org/ monthly-forecast/2019-02/lead-roles-within-the-council-in-2019-penholders-and -chairs-of-subsidiary-bodies.php.

Sievers, Loraine, and Sam Daws. The Procedure of the UN Security Council, 4th ed. (Oxford: Oxford University Press, 2014).

Sievers, Loraine, and Sam Daws. "With Adoption of Three Key Documents, Momentum Accelerates for Enhanced E1o Impact." Update website of The Procedure of the UN Security Council, 4th ed., 2018. https://www.scprocedure.org/chapter-3-section-3i.

Tardy, Thierry, and Zaum, Dominik. "France and the United Kingdom in the Security Council." In The UN Security Council in the Twenty-First Century, eds. Sebastian von Einsiedel, David M. Malone, and Bruno Stagno Ugarte (Boulder: Lynne Rienner, 2016), 121-138.

Thompson, Alexander. Channels of Power: The UN Security Council and US Statecraft in Iraq (New York: Cornell University Press, 2010).

Thorhallsson, Baldur. "Small States in the UN Security Council: Means of Influence?" The Hague Journal of Diplomacy 7 (2) (2012), 135-16o.

Traub, James. "Unwilling and Unable: The Failed Response to the Atrocities in Darfur." 
Occasional Paper Series (Global Centre for the Responsibility to Protect, New York, 2010) http://www.globalr2p.org/media/files/unwilling-and-unable-the-failed-respo nse-to-the-atrocities-in-darfur.pdf.

Trenin, Dmitri. "Russia in the Security Council." In The UN Security Council in the Twenty-First Century, eds. Sebastian von Einsiedel, David M. Malone, and Bruno Stagno Ugarte (Boulder: Lynne Rienner, 2016), 105-119.

UN. Charter of the United Nations (New York: UN, 1945).

UN. "Provisional Rules of Procedure of the Security Council" (New York: UN, 1982).

UN. A More Secure World: Our Shared Responsibility. Report of the High-Level Panel on Threats, Challenges and Change (New York: UN, 2004).

UN. "Security Council Meetings." (New York: UN, 2020) https://research.un.org/en/ docs/sc/quick/meetings/2O2O.

UN Security Council. “5727th Meeting United Nations Security Council.” UN S/PV.5727 (New York: UN, 2007).

UN Security Council. "Note by the President of the Security Council" UN S/2017/507 (New York: UN, 2017).

Urquhart, Brian E. "The Evolution of the Secretary-General." In Secretary or General? The UN Secretary-General in World Politics, ed. Simon Chesterman (Cambridge: Cambridge University Press, 2007), 15-32.

von Einsiedel, Sebastian, David M. Malone, and Bruno Stagno Ugarte. "The UN Security Council in an Age of Great Power Rivalry." Working Paper Series 04 (Tokyo: United Nations University, 2015). https://i.unu.edu/media/cpr.unu.edu/attachment/1569/ WPo4_UNSCAgeofPowerRivalry.pdf.

von Einsiedel, Sebastian, David M. Malone, and Bruno Stagno Ugarte, eds. The UNSecurity Council in the 21st Century (Boulder: Lynne Rienner, 2016).

Wallensteen, Peter, and Patrik Johansson. "Security Council Decisions in Perspective." In The UN Security Council: From the Cold War to the 21st Century, ed. David M. Malone (Boulder: Lynne Rienner, 2004), 17-33.

Weiss, Thomas G., David P. Forsythe, Roger A. Coate, Kelly-Kate Pease. The United Nations and Changing World Politics, $5^{\text {th }}$ ed. (Boulder: Westview Press, 2007).

Wenaweser, Christian. "Working Methods: The Ugly Duckling of Security Council Reform." In The UN Security Council in the Twenty-First Century, eds. Sebastian von Einsiedel, David M. Malone, and Bruno Stagno Ugarte (Boulder: Lynne Rienner, 2016), 175-194.

Wenqi, Zhu, and Leng Xinyu. "China in the Security Council." In The UN Security Council in the Twenty-First Century, eds. Sebastian von Einsiedel, David M. Malone, and Bruno Stagno Ugarte (Boulder: Lynne Rienner, 2016), 83-103.

Wikileaks. "AU/UN Hybrid in Darfur: Narrowing Differences." 2007. http://wikileaks .org/cable/2007/o7/o7USUNNEWYORK563.html\#.

Yamashita, Hikaru. "Reading 'Threats to International Peace and Security' 1946-2005." Diplomacy and Statecraft 18 (3) (2007), 551-572. 